Article

\title{
Seasonal Accumulation and Depletion of Local Sediment Stores of Four Headwater Catchments
}

\author{
Sarah E. Martin, Martha H. Conklin * and Roger C. Bales
}

Sierra Nevada Research Institute at the University of California, Merced, 5200 N Lake Rd., Merced, CA 95343, USA; E-Mails: mconklin@ucmerced.edu (M.C.); rbales@ucmerced.edu (R.B.)

* Author to whom correspondence should be addressed; E-Mail: mconklin@ucmerced.edu; Tel.: +1-209-228-4349; Fax: +1-209-228-4158.

Received: 1 May 2014; in revised form: 8 July 2014 / Accepted: 8 July 2014 /

Published: 23 July 2014

\begin{abstract}
Seasonal turbidity patterns and event-level hysteresis analysis of turbidity verses discharge in four $1 \mathrm{~km}^{2}$ headwater catchments in California's Sierra Nevada indicate localized in-channel sediment sources and seasonal accumulation-depletion patterns of stream sediments. Turbidity signals were analyzed for three years in order to look at the relationships between seasonal turbidity trends, event turbidity patterns, and precipitation type to stream sediment production and transport. Seasonal patterns showed more turbidity events associated with fall and early to mid- winter events than with peak snow-melt. No significant turbidity patterns emerged for periods of snow melt vs. rain. Single event hysteresis loops showed clockwise patterns were dominant suggesting local sediment sources. In successive discharge events, the largest turbidity spike was often associated with the first but not necessarily the largest discharge event-indicating seasonal depletion of local sediment stores. In multi-peaked discharge events, hysteresis loops shifted from clockwise to linear or random patterns suggesting that localized sediment stores are being used up and sufficient flow energy must be reached to start entraining the more consolidated bank/bed sediment or that dominant sediment sources may be shifting to less localized areas such as hill slopes. A conceptual model with phases of accumulation and transport is proposed.
\end{abstract}

Keywords: hysteresis; sediment; snowmelt; storm event; turbidity 


\section{Introduction}

This research analyzes the seasonal turbidity and event-level hysteresis patterns of turbidity versus discharge in four $1 \mathrm{~km}^{2}$ headwater catchments in the Sierra Nevada, California. Turbidity events in this region are reported to be infrequent and of short duration [1]. Turbidity event patterns can vary on multiple time scales as the controlling factors on erosion and sediment transport vary. Understanding the patterns of turbidity events and source areas of sediment within watersheds will allow managers to better target erosion-control measures and to better plan for turbidity-related impacts to downstream water quality.

Fine sediments that remain in suspension and cause turbidity signals in streams can come from hillslope or in-channel sources. On hillslopes and floodplains, the relevant sediment production processes may include soil creep, rain splash, overland flow, bioturbation, and snow creep [2]. In-channel processes that can act on banks include mass failure, freeze thaw cycles, drying and crumbling, fluvial erosion during high flows, and bioturbation [2]. In-channel erosion processes that act on the channel bed are generally a form of fluvial erosion (i.e., re-suspension or vertical incision). Previous work in stream systems similar to those in this study has suggested that in-channel erosion of the bed and banks are the more important processes in forested mountain headwater catchments [3].

Turbidity and suspended sediment are controlled not only by discharge but also by erosion and transport processes causing accumulation and depletion of sediment that can vary spatially and temporally within a watershed or event [4]. The processes which factor into producing a turbidity signal often depend on the interplay between physical watershed features (i.e., gradient, soil porosity, and vegetation cover), sediment availability, precipitation attributes (i.e., amount, intensity, rain vs. snow) and antecedent moisture conditions of the soil. Because of these additional controls on turbidity, typical rating curves based on linear regressions between discharge and suspended sediment concentrations tend to perform poorly for predicting turbidity or sediment loads [4-7].

The offset of turbidity or suspended sediment peaks from discharge peaks, termed hysteresis effect, can provide insight into sediment movement within watersheds. Hysteresis analysis has long been established as a technique for examining sediment source areas or processes in a wide range of watershed sizes and types based on the shape of discharge-sediment hysteresis loops. The temporal relationship between the turbidity peak and the discharge peak can indicate the proximity of the sediment source and whether or not sediment depletion is occurring [8,9]. Early papers by Wood [8] and Williams [9] identified a hysteresis effect and related each hysteresis type to physical processes in the streams. Hysteresis loops are classified into five types [9]. Clockwise patterns are produced when turbidity peaks occur before discharge peaks indicating a localized sediment source and/or depletion of the source. Counterclockwise patterns occur when turbidity peaks occur after discharge peaks, indicating a more distant sediment source, a discharge threshold that must be reached to entrain consolidated bank sediments, or a rainfall threshold required to initiate overland flow. Linear patterns, where peaks occur simultaneously, imply a sediment source at an intermediate distance, a lower entrainment threshold, or a continuous supply of sediment. Figure eight and complex patterns typically occur when there are multiple sediment source locations or multiple erosion processes acting concurrently. 
Over the past several decades, a significant amount of research has been done on the relationships between precipitation, discharge, and sediment transport. However, much of this work has been focused on individual discharge events [10-12], or has been in predominately agricultural areas [4,6,7,11-13], in small hillslope plots [11] or in areas with drastically different physiographic and climatic regimes [7,14,15]. A few longer studies looking at multiple time scales have shown considerable temporal variation in sediment patterns. McDonald and Lamoureux [15] found significant temporal variation in suspended sediment transport in High Arctic catchments that was linked to snow melt. Rodriguez-Blanco et al. [6] found for agricultural basins in Spain that at the event scale sediment peaked before discharge, at the seasonal time scale sediment yield decreased through the season, and at the annual scale yield was linked to the percentage of the year that large events occurred. For a medium sized basin in Central New York, Gao and Josefson [7] found event and seasonal patterns to be too complex to identify sources or processes but they did show that in their system, event sediment was generally supply limited. Iida et al. [16] looked at hysteresis patterns associated with snow melt in a temperate mountain catchment in Japan. They found that more sediment moved during the snow melt season than the rest of the year and that a shift from clockwise to counter-clockwise hysteresis patterns occurred as the snow melt season progressed. Fang et al. [14] found differences in the sediment-discharge hysteresis patterns between the hillslope plot (clockwise) and small basin scales (counterclockwise) that implied a hillslope source area in the Loess Plateau of China. Headwater and larger order basins in southeast Australia were studied by Smith and Dragovich [17] who suggested that differences in sediment patterns were due to rates of sediment transfer to larger order basins.

Work in small, forested mountain catchments with a Mediterranean climate has been limited. Seeger et al. [18] showed for a basin in the central Spanish Pyrenees that seasonal differences in hysteresis loop patterns were tied to antecedent conditions within the basin. In their work in the Lake Tahoe region, Langolis et al. [5] showed fairly consistent clockwise sediment-discharge patterns for the snow melt season, but did not look at other seasons.

An understanding of sediment in small headwater catchments in mountain areas is important as they are a main water source and often a dominant sediment source area [19]. This is especially true in California where 60 percent of the water comes from the Sierra Nevada and most of the major river systems contain dams where storage area can be greatly reduced by accumulating sediment [19]. Several case studies on California reservoirs have shown that the fine sediment fraction (silt, clay, and sand), which can cause turbidity in headwater reaches, accounts for the majority of accumulated sediment in reservoirs [20,21]. Sediment and sediment transport also play a key role in nutrient cycling, aquatic-habitat quality, flood-control and water-supply infrastructure, and contaminant transport [22]. Knowing where the sediment source areas are located for a given event and how the source areas may change on an event, seasonal, or annual time scale can provide insight into what types of erosion processes dominate within a watershed. Identification of sediment source areas, transport patterns, and erosion processes can aid in managing watersheds and mitigating sediment driven watershed degradation. This information can help policy makers and land/water managers target erosion prone areas or erosion prone time periods with control efforts such as Best Management Practices. A better understanding of sediment sources and their event, seasonal, and annual variability can also aid sediment and water-quality modeling in catchments. Finally, an understanding of how sediment 
transport is affected by seasonal conditions (i.e., snow cover) is key to planning for seasonal precipitation changes associated with climate change.

The aim of this study was to use high-temporal-scale discharge, turbidity, and precipitation data from forested mountain catchments to address the following questions: (1) What are the seasonal trends in turbidity patterns? What do these patterns imply about sediment production and sediment transport throughout the water year in these catchments? (2) What are the turbidity patterns associated with individual storm events? What do these patterns imply about sediment sources and sediment transport? (3) How does the source of water (i.e., rain, snow-melt, and rain on snow) to the stream affect the discharge and turbidity response of the stream? What does this imply about water flow pathways and sediment movement in the catchments?

\section{Experimental Section}

\subsection{Study Area}

Field sites for this study consist of a northern and southern site, each with two headwater catchments. The southern site (Sugar Pine) is located in the Merced River basin near Fish Camp, CA and the northern site (Last Chance) is located in the American River basin near Foresthill, CA (Figure 1). Data are presented from Water Year (WY) 2010 through WY 2012.

Figure 1. Map of Last Chance (A) and Sugar Pine (B) study areas.
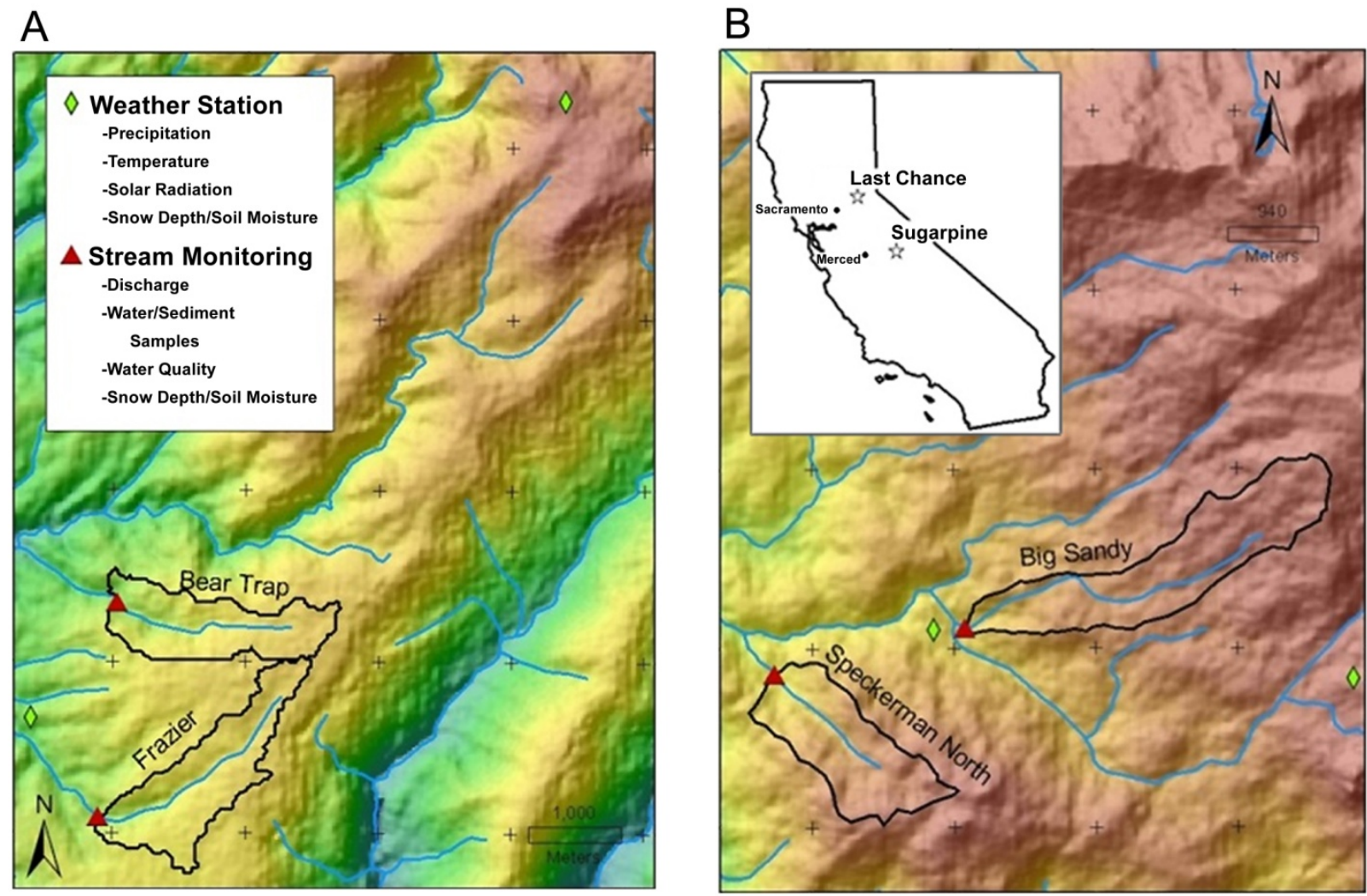

The two catchments at the Last Chance site are Frazier Creek and Bear Trap Creek. The catchments at the Sugar Pine site are Big Sandy Creek and Speckerman Creek. The paired catchments were chosen based on comparable size, gradient, discharge, aspect, and vegetation cover (Table 1). All catchments 
have perennial streams located on the western slope of the Sierra Nevada. The study area is characterized by a Mediterranean climate with a distinct wet and dry season and is located in the rain-snow transition zone, with snow making up roughly 40 to 60 percent of average annual precipitation.

Table 1. Study watershed characteristics.

\begin{tabular}{ccccc}
\hline Attribute & Frazier Creek & Bear Trap Creek & Big Sandy Creek & $\begin{array}{c}\text { Speckerman } \\
\text { Creek }\end{array}$ \\
\hline River basin & American & American & Merced & Merced \\
\hline Elevation $(\mathrm{m})$ & 1605 & 1580 & 1778 & 1719 \\
\hline Area $\left(\mathrm{km}^{2}\right)$ & 1.68 & 1.76 & 2.47 & tonalite \\
\hline Geology & andesitic volcanics; & andesitic volcanics; & tonalite & loamy sand/sand \\
\hline Sondstones/siltstones/slates & sandstones/siltstones/slates & loamy sand/sand & mixed conifer \\
\hline Vegetation & sandy loam/loam & sandy loam/loam & 83-214 & $83-214$ \\
\hline Annual & mixed conifer & mixed conifer & $120-255$ & 120-255
\end{tabular}

Note: * Annual precipitation range for study met stations' period of operation WY 2008-WY 2013.

\subsection{Instrumentation}

Two meteorological stations were also located at each site at elevations similar to the upper portion of the basins and to the catchment outlets. Lower meteorological stations were at $1755 \mathrm{~m}$ and $1590 \mathrm{~m}$, while upper elevation meteorological stations were at $2176 \mathrm{~m}$ and $2112 \mathrm{~m}$ for Sugar Pine and Last Chance sites respectively. Meteorological stations were located on flat open ridges with snow and soil-moisture sensors located adjacent to meteorological stations on north-facing and south-facing hillslopes. Stream instrumentation was located along a relatively low-gradient response reach where sediment scour and deposition are likely to occur.

Turbidity was measured in situ at 15-min intervals using 6136 optical turbidity sensors from Yellow Springs Instruments (YSI) mounted on 6920 YSI multiparameter sondes that were either self logging or attached to a CR1000 datalogger from Campbell Scientific. Sondes were switched from internal battery power to a solar panel and external battery source partway through WY 2011 due to issues with battery failure. At that time, 600OMS YSI sondes outfitted with a 6136 YSI optical turbidity sensor, were co-located with the 6920 sondes for data redundancy and backup. The 6136 YSI sensor uses a near infrared LED to illuminate a sample of the water column and measures back-scattered light with an adjacent photodiode. The range of the sensor is 0 to 1000 NTU [23]. Anti-fouling wipers are installed on the sensors to prevent buildup of sediment or algae on the optical ports. Wipers ran before each data collection and were replaced as needed every two to three months.

Stream stage was measured at two locations using pressure sensors. At the upstream location, stream stage was measured using a depth sensor calibrated for shallow depth deployments and built into the 6920 YSI sonde. At the downstream location, slightly upstream of the culvert marking the outlet of each catchment, stage was measured using a Solinst Levelogger Gold pressure transducer. The two stage measurements were located 100 to $300 \mathrm{~m}$ apart. 
Snow depth was measured at all instrument nodes and meteorological stations using Judd ultrasonic depth sensors. Meteorological station sensors were mounted on the meteorological tower and hillslope sensors mounted on the end of an L-shaped rigid metal conduit structure approximately $3 \mathrm{~m}$ high. Sensors were positioned so that the surface of the transducer was parallel to the ground. 1-6 sensors were deployed at each hillslope node. They were located on upper or lower banks near the stream sites and under canopy, under drip edge or in the open for several different tree species at the nodes adjacent to meteorological stations. Snow depth was measured at the meteorological stations on hourly intervals for the beginning of the study and changed to 15-min intervals in WY 2011. Hillslope snow measurements were taken at 15-min intervals for the full period of record. Each snow-depth value represents an average of multiple measurements taken over that time interval.

Decagon Devices $\mathrm{ECH}_{2} \mathrm{O} \mathrm{TM}$ soil temperature and moisture sensors were installed at hillslope sensor nodes and were collocated with snow-depth sensors. Nodes were sited on the north- and south-facing hillslopes adjacent to the meteorological station ridges and on the north- and south-facing banks adjacent to the stream instrumentation. Sensor installation depths ranged from 10 to $90 \mathrm{~cm}$ but were generally confined to 30 and $60 \mathrm{~cm}$ due to the shallow nature of the soils. Each node consisted of 6 to 12 soil-moisture sensors.

Precipitation was measured at meteorological stations using a Handar 444B tipping-bucket rain gage. Each tipping-bucket assembly was mounted on the meteorological tower 4.5 to $5 \mathrm{~m}$ above the ground. Because the rain gages at the study sites were unshielded and unheated, data from nearby rain gages were used to supplement site data. The nearby station precipitation data were used because of the higher accuracy associated with shielded, heated gages in windy or sub freezing conditions. For the northern sites the US Bureau of Reclamation Blue Canyon station was used and for the southern sites US Bureau of Reclamation Chilkoot Meadow and US Army Corps of Engineers Westfall stations were used.

Bank erosion pins were used to measure rates of bank erosion in the southern catchments according to methods outlined in Martin [24]. Attempts were made to install erosion pins in the northern sites, but the stream beds and banks were too rocky (cobble, boulder, and bedrock) to insert rebar pins. Bank-pins were installed in the summer of 2008 and resurveyed each year in late summer or early fall.

A typical bank-pin station consisted of rebar bank pins placed horizontally into the banks perpendicular to the channel and a rebar toe pin pounded vertically into the channel bottom in line with the bank pins. At each station, a bank profile survey was measured with a vertical rod at the base of the toe pin and with a horizontal rod, measuring the distance to the bank at all the slope breaks (changes in bank angle). For each slope break point, a horizontal distance and vertical height were recorded. Locations (vertical stationing) of each bank pin and the distance it stuck out from the bank were also recorded.

\subsection{Data Analysis}

Turbidity data were manually checked to remove any erroneous spikes due to maintenance of sensors, sampling in the stream, or periods when the 6920 Sonde was buried in sediment. To reduce background sensor noise the turbidity data were filtered to remove any values less than 5 NTU. The remaining values were considered actual turbidity events and were used in analysis. 
Stage data were manually cleaned, barometrically corrected, and then gap filled. Manual cleaning involved removing any erroneous values due to sensor maintenance or other field activities and adjusting stage levels if a sensor was redeployed at a new depth. Using data collected at the lower meteorological stations with a Solinst Barologger Gold, barometric corrections were performed. Gaps were filled using a linear regression if data were missing for time periods less than 3 hours. The two stage sensors within each stream correlated well so if gaps were more than 3 hours duration, data from the other stage instrument within the same stream were used to gap fill. Occasionally, as in Bear Trap Creek WY 2011 there was overlap in the gaps from the two instruments and gap filling was not possible.

Rating curves were created for each catchment using manual discharge measurements and processed stage data; these were used to calculate discharge. The manual measurements were taken using a slug-tracer dilution method on a monthly to bimonthly basis [25]. Attempts were made to capture the full range of high-flow and low-flow events, though site access made the high-flow measurements more difficult. Sediment hysteresis loops were created by plotting turbidity $v s$. discharge for each event. Turbidity spikes not associated with a discharge peak were not included in the analysis. Graphs were visually inspected and classified into clockwise, counterclockwise, linear, figure eight, or complex hysteresis shape categories [8,9].

A two-week running average was computed for the discharge records to represent the background level (non-storm event) discharges. These running averages were used in determining the number of storm events per season and per hysteresis pattern by counting events that were more than $0.10 \mathrm{~m}^{3} / \mathrm{s}$ above background flows. Flow intensity was calculated by determining the difference between the peak and the background discharge. High flow events were defined as the top three largest discharge events per water year per catchment. Data from Bear Trap creek in WY 2011 were left out of analysis due to the large gap in data during winter and spring. For this analysis, fall is defined as from the first fall rain events to the beginning of persistent snow. Early to mid winter comprises from the first persistent snow to peak snowpack accumulation. Melt season comprises from peak accumulation to full melt out of the snow pack, and base flow refers to the period from full melt of snowpack to first fall rain.

Hysteresis loops were generated for all turbidity events greater than $1 \mathrm{~h}$ in duration according to methods described by Wood [8] and Wilson [12]. These loops were categorized based on the direction and pattern of the loop. Then loops were compared by season and watershed.

Snow-depth values were manually cleaned to remove spikes that occur during periods of precipitation due to the signal bouncing off falling snow or rain. The cleaned data was gap filled using a linear regression for gaps less than 1 day. Data for each node were then averaged and a daily average node value calculated.

A precipitation separation between rain and snow was computed on the nearby met station precipitation data using snow-depth data from the study-site meteorological station. For a given day with precipitation, if snow depth at the study sites increased, the precipitation was assumed to be mainly snow and the nearby station precipitation record was classified as snow for that day. If precipitation at the nearby sites did not accompany a snow-depth increase at the study sites, that precipitation was assumed to be rain. Snow-density data from nearby US Bureau of Reclamation snow-pillow sites were used to compute snow water equivalent (SWE) for the stream and meteorological station locations according to the method outlined in Liu et al. [26]. The Blue Canyon station was used for the northern site and a combination of the Chilkoot Meadow and Poison Ridge stations for the southern site. Data 
was obtained through the California Department of Water Resources California Data Exchange Center. From the snow-depth and SWE data reported by these pillows, a daily snow-density product was calculated. A linear regression line was fitted to the data and a general relationship between water year day and snow density was found. This relationship was applied to the site-average daily snow depths at the study site meteorological stations and stream sites to calculate the daily SWE.

A snowmelt product was calculated for each site from the calculated SWE. If SWE decreased from one day to the next it was assumed that melt was occurring and a SWE-based snowmelt record was created from the values.

Post processing of soil moisture included manually cleaning data from each sensor to remove erroneous values and averaging the instruments at each node to produce a single record. Node data were then aggregated from $15 \mathrm{~min}$ data to $24 \mathrm{~h}$ average values. Contiguous $24 \mathrm{~h}$ average values were compared and where that change was positive, it was assumed that soil moisture was increasing due to rain or snowmelt. The positive $24 \mathrm{~h}$ changes due to rain were filtered out using the rain record and the remaining values represented a snowmelt record (i.e., the soil moisture increase due to snowmelt). The soil moisture derived snow melt was compared to a SWE derived snow melt product with the two methods showing good agreement for days with and without snow melt. The SWE-based product was chosen for analysis because it was a more direct measurement of snowpack water loss without influences such as vegetation uptake, or groundwater input from upslope areas.

\section{Results and Discussion}

WY 2010 and WY 2011 were above average years, and WY 2012 was below average. The percentage of the average historical April 1 snow course SWE was calculated for two snow courses: Poison Meadow near the southern sites (elevation $2070 \mathrm{~m}$ ) and Huysink near the northern site (elevation $2010 \mathrm{~m}$ ) (Table 2). A Sierra Nevada wide percentage of average was included for comparison. Big Sandy Creek and Frazier Creek had an average of $0.023 \mathrm{~m}^{3} / \mathrm{s}$ and $0.038 \mathrm{~m}^{3} / \mathrm{s}$ higher flows than their paired catchments, but pairs are similar in timing of events (Figure 2). The largest discharge events generally occurred during the early to mid winter or snow melt seasons with the exception of an early fall rain event in WY 2011 that produced particularly high discharges in Big Sandy creek. Turbidity events vary greatly in magnitude for WY 2010 to WY 2012 and not all storm events produced a turbidity signal (Figure 2).

Table 2. Percentage of mean April 1 snow pack SWE for Poison Meadow snow course, Huysink snow course, and Sierra Nevada range average for WY 2010 through 2012*.

\begin{tabular}{cccc}
\hline Water Year & Poison Meadow & Huysink & Sierra Nevada \\
\hline 2010 & $168 \%$ & $101 \%$ & $143 \%$ \\
2011 & $206 \%$ & $114 \%$ & $144 \%$ \\
2012 & $47 \%$ & $56 \%$ & $55 \%$ \\
mean $\mathrm{SWE}^{\dagger}$ (standard deviation) & $65(40) \mathrm{cm}$ & $111(41) \mathrm{cm}$ & \\
\hline
\end{tabular}

Notes: * Data from CA Department of Water Resources; ${ }^{\dagger}$ Values are based on 68 years of 1 April snow pack data at Poison Meadow and 75 years at Huysink. 
Figure 2. Precipitation, discharge, and turbidity data for (A) Sugar Pine and (B) Last Chance sites for WY 2010-WY 2012. Snow values are averaged across the study area. The light grey shaded areas indicate periods when turbidity data were not available.
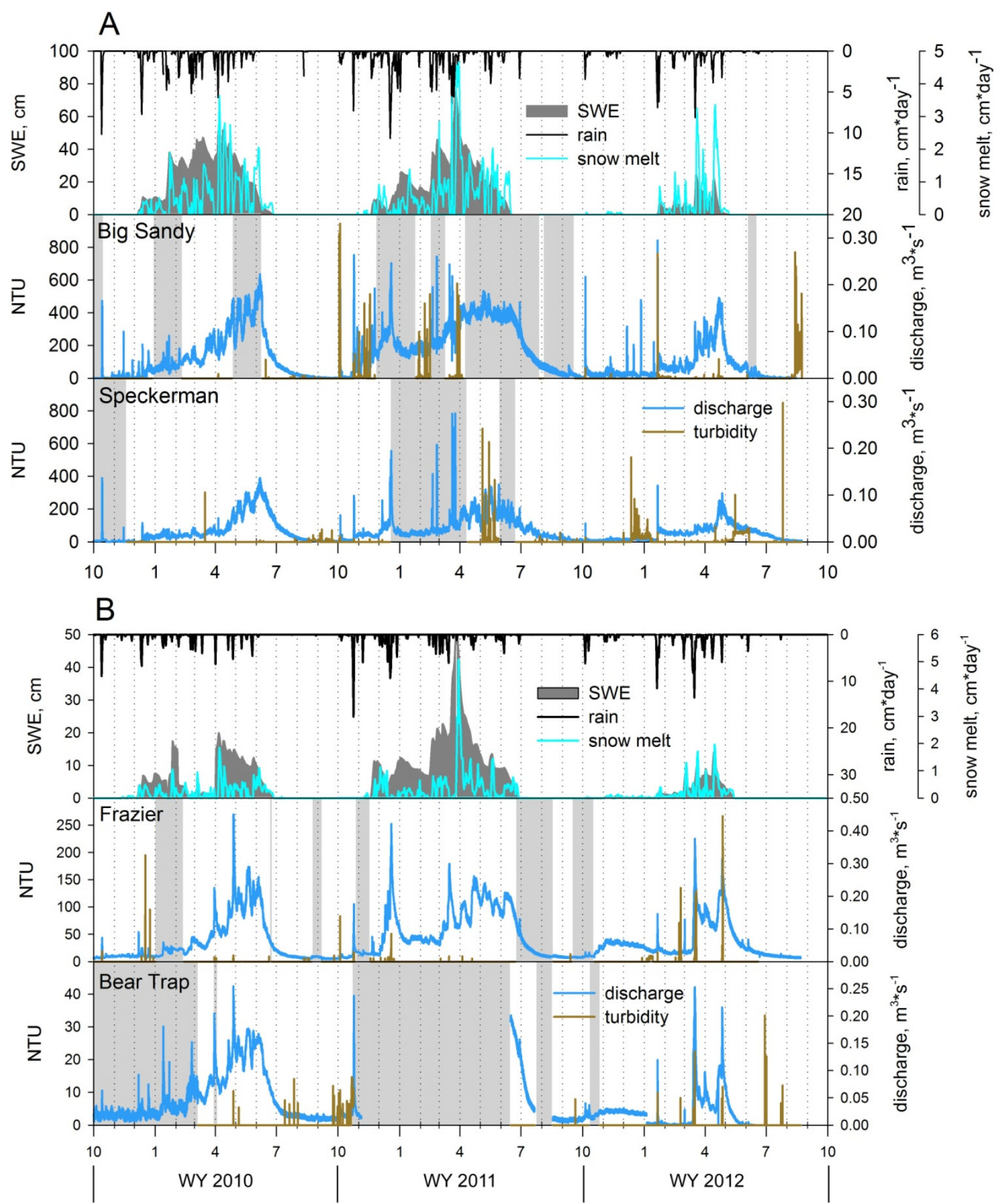

It was found that in all four watersheds, fall flow events were most likely to produce turbidity signals compared to events in other seasons, with a progressive reduction in percentage of events producing a turbidity signal seen through the water year (Table 3, Figure 2). The fall discharge events were more likely to produce turbidity signals despite the fact that the largest storms typically do not occur during that season. A number of factors could lead to this pattern, such as fall events occurring after a summer dry period, when loose sediment can accumulate at the toe of channel banks or on near 
channel soil surfaces, so there is more material available to transport [24]. In early fall, there also may be some hydrophobicity of dry soils leading to a portion of runoff being moved as overland or very shallow surface (duff layer) flow and more material reaching the stream [27,28]. Finally, fall's larger turbidity signals may be due to the fall rain events representing the most abrupt discharge increases (Table 4, Figure 2). If it is assumed that at steady background discharge levels all transportable sediment at that flow level has been moved, then any increases in flow from that level likely means more sediment will be moved. The greater the increase from background levels, the greater the amount of additional sediment that can be transported due to increased flow energy. Though there are somewhat larger flows during spring events than fall events, the non-event, background flow in spring is fairly high so there is less of an increase in flow with each event, and therefore less of an increase in flow erosivity and fluvial entrainment. Data show that fall discharge events had the highest average flow increases and were almost double the average flow increase of snow melt period discharges (Table 4). These results are consistent with those of Duvert et al. [29], Rodriguez-Blanco et al. [6], and Seeger et al. [18] who observed that there are significant seasonal differences in sediment transport and that turbidity is not only tied to the absolute value of the event discharge but also to event intensity.

Table 3. Percentage of flow events producing turbidity and number of flow events by season for all catchments.

\begin{tabular}{ccc}
\hline Season & $\begin{array}{c}\text { Percentage of flow events that } \\
\text { produce a turbidity signal }\end{array}$ & $\begin{array}{c}\text { Number of large } \\
\text { flow events * }\end{array}$ \\
\hline Fall & $84.2 \%$ & 0 \\
Early/Mid winter & $55.6 \%$ & 11 \\
Snow melt & $49.0 \%$ & 18 \\
Base flow & $44.4 \%$ & 4 \\
\hline
\end{tabular}

Note: * Large flow events consist of the three largest discharge events of each water year for each stream.

Table 4. Intensity values for discharge peaks $\left(\mathrm{m}^{3} \mathrm{~s}^{-1}\right)$ by season.

\begin{tabular}{|c|c|c|c|}
\hline Season & $\begin{array}{c}\text { Average Intensity Values * for Discharge } \\
\text { Peaks (Standard Deviation) }\end{array}$ & $\begin{array}{l}\text { Number } \\
\text { of Peaks }\end{array}$ & $\begin{array}{c}\text { Number of } \\
\text { Measurement Days }\end{array}$ \\
\hline Fall & $0.11(0.06)$ & 17 & 536 \\
\hline Early/Mid Winter & $0.10(0.05)$ & 60 & 1501 \\
\hline Snow Melt & $0.06(0.04)$ & 52 & 743 \\
\hline Base Flow & 0.06 & 1 & 1156 \\
\hline
\end{tabular}

Notes: * Intensity values equal the peak discharge values minus the background discharge as defined by 15 day running average; ${ }^{\dagger}$ Discharge peaks are defined as peaks where intensity values are greater than $0.04 \mathrm{~m}^{3} / \mathrm{s}$;

* Measurement days are the number of days summed by the four watersheds minus the days when no data was collected.

When multiple discharge events occurred in succession, the largest turbidity spike was often associated with the first event rather than the largest event. An example of this pattern can be seen in the fall 2010 Speckerman turbidity and discharge data (Figure 3). During this fall rainy season, the largest turbidity peak was associated with the first set of rain events, even though those events 
produced a relatively small discharge response. As the season progressed discharge peaks became larger, but turbidity peaks became smaller.

The reduction in peak turbidity values throughout a season is likely related to a seasonal depletion of sediment stores $[6,10]$. At the beginning of certain seasons there are stores of easy to transport sediment in the channel. The first storm moves a large portion of sediment out of the local area and with each successive storm and associated transport, less and less loose, easy to move sediment is available. This "first flush" is a common phenomenon and has been reported by numerous researchers across a wide range of watershed sizes $\left(0.3 \mathrm{~km}^{2}\right.$ to $\left.311 \mathrm{~km}^{2}\right)$, elevations $(120 \mathrm{~m}$ to $3340 \mathrm{~m}$ above sea level), and precipitation regimes (seasonal snow dominated to year round rain dominated) $[7,12,16,29]$. In the study catchments, the "first flush" signal occurs strongest during early fall rainstorms.

Figure 3. Turbidity, discharge, and precipitation data from Speckerman Creek for the fall rainy season, WY 2011.

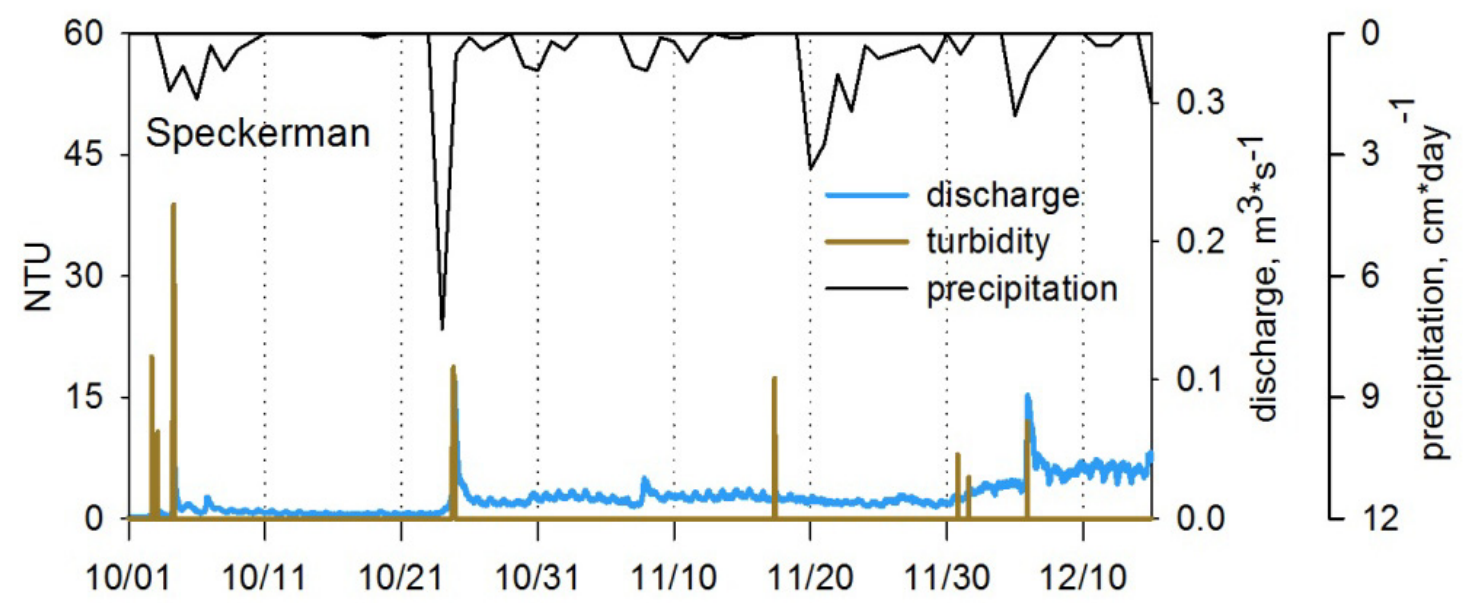

Peak turbidity values ranged widely in all seasons (Figure 2). Snow melt season had the highest average values for turbidity peaks and fall had the next highest average values (Table 5). Early/mid winter and base flow seasons had similar average values and they were the lowest values of the four seasons. Interestingly, even though the snow melt season had the highest average values, it had the lowest maximum value of all the seasons (Table 5).

Table 5. Peak event turbidity values (NTU) by season.

\begin{tabular}{ccccc}
\hline Season & $\begin{array}{c}\text { Average peak event values } \\
\text { (Standard deviation) }\end{array}$ & $\begin{array}{c}\text { Median peak } \\
\text { event value }\end{array}$ & $\begin{array}{c}\text { Min peak } \\
\text { event value }\end{array}$ & $\begin{array}{c}\text { Max peak } \\
\text { event value }\end{array}$ \\
\hline Fall & $76(218)$ & 12.2 & 5 & 946 \\
Early/Mid winter & $36(107)$ & 9.6 & 5 & 763 \\
Snow melt & $92(172)$ & 11.9 & 5 & 692 \\
Base flow & $35(120)$ & 11.5 & 5 & 850 \\
\hline
\end{tabular}

Higher average peak turbidity values but lower max peak turbidity values for the snow melt season compared to fall indicates that there is less variation in sediment events within the snow melt season. Average peak turbidity values likely tend to be higher due to the snow melt season having high background flow levels. Higher discharge events mean greater flow energy and therefore greater 
potential to transport sediment in an event. Other potential explanations are (i) there may be rain-on-snow events that produce a high runoff response; (ii) preferential flow paths through the snowpack may produce concentrated channelized flow at the soil- snowpack interface and facilitating the rapid transport of hillslope sediment to the stream; (iii) saturated soil conditions may increase the likelihood of overland flow that can transport sediment directly to the stream; (iv) snow related erosion processes may produce a store of loose material that is easy to transport; or (v) differences in the particle size class of sediment transported can result in differences in NTU values. [23,30]. The high sand content in the soils within the study catchments and low erosion rates on undisturbed hillslopes in the Sierra Nevada suggest overland flow is not a likely explanation for the seasonal differences [3]. Seasonal variations in transported particle size classes is also an unlikely explanation for the difference because size variations only cause up to $10 \mathrm{NTU}$ fluctuations in data readings for the turbidity sensors used in this study [23].

The relatively high average event values in fall despite lower discharges were expected because of the intensity of fall discharge events and the in-channel stores of loose sediment. These data match well with findings by Rodriguez-Blanco et al. [6] despite major differences in land use and rainfall patterns between the two studies. These Rodriguez-Blanco et al. [6] authors reported fall having the largest sediment load and runoff (50 percent of the annual) but only 29 percent of the water yield. In their study, the large fall sediment loads were attributed to fall having the highest number of rainfall events as well as to the presence of bare ground in fall due to traditional agricultural practices within their catchments. Results from both the Rodriguez-Blanco et al. study and this one suggest there may be strong accumulation/depletion patterns occurring in the summer and fall where a large amount of sediment is available for transport in the early season leading to very large peak turbidity values but sediment stores quickly depleting resulting in a lower average for the fall compared to the snow melt season. It is likely that less accumulation of sediment occurs in the early/mid winter so the snow melt season had less variation in sediment availability and thus a smaller range for NTU values.

The low average values for early/mid winter and base flow seasons may suggest that these seasons are both times of sediment accumulation where erosion outpaces transport. Both seasons are characterized by flow being low compared to the season immediately following it. During base flow, channel banks are drying out and crumbling and bio-turbation is at its highest in summer when plants and animals are most active [2]. During early and mid winter, processes such as freeze-thaw cycles and snow creep generate loose sediment from the banks and the nearby hillslopes [2].

Prior research has shown conflicting results on the dominate season for sediment transport, but generally the seasons of highest flow tended to also be the seasons with the highest suspended sediment concentrations. Rodriguez-Blanco et al. [6] showed in a steep, low elevation, $16 \mathrm{~km}^{2}$ basin in northwest Spain with no seasonal snow, that most sediment events and most suspended sediment load transport occurred in the fall, the season of highest volume of runoff and the highest number of events. Research in a mountainous catchment in Japan which is lower elevation but with a similar snow dominated precipitation pattern as this study's sites found that over $60 \%$ of the basins suspended sediment load was transported during the spring snow melt period [16].The high spring snow melt sediment load was attributed to increased discharge. Finally, Gao and Josefson [7] did not see a dominant sediment transport season for a medium sized, low elevation, central New York catchment with patchy seasonal snow cover. Instead they showed that most of the sediment was transported 
throughout the year during frequent small events. The differences between their results and those of this study are likely due to differences in the amount and types of precipitation throughout the year. Their catchments had much higher year round precipitation and high intensity or high volume rainfall/melt events were not concentrated to a specific time period. Additionally, their study sites comprised of $50 \%$ agricultural lands which may have provided a steady year round hillslope sediment source to the streams. Sites in the current study are most similar to the forested, snow dominated catchments from Iida et al. [16] and share the high spring snow melt turbidity signal. However, the strong summer accumulation-fall depletion cycle and the high intensity of fall rain events result in an additional high turbidity season in fall in this study.

All five types of hysteresis loops were seen in this study (Figure 4). When separated by study catchment, it was seen that a clockwise hysteresis loop pattern for individual storm events was dominant for all catchments (Table 6) occurring five to ten times more frequently than other patterns. The exception was Bear Trap, which was likely due to significant missing data and was not reflective of a naturally lower proportion of events. These results were as expect because paired streams have similar physical properties and similar discharge responses for a given storm. The mainly clockwise patterned events imply that localized in-channel sources dominate sediment supply in these catchments. One would expect to see this in small mountain catchments because these are typically sediment source areas [31].

Figure 4. Examples of each of the five hysteresis loop shapes seen in the study area (A) clockwise; (B) counter clockwise; (C) linear; (D) figure eight; and (E) complex.

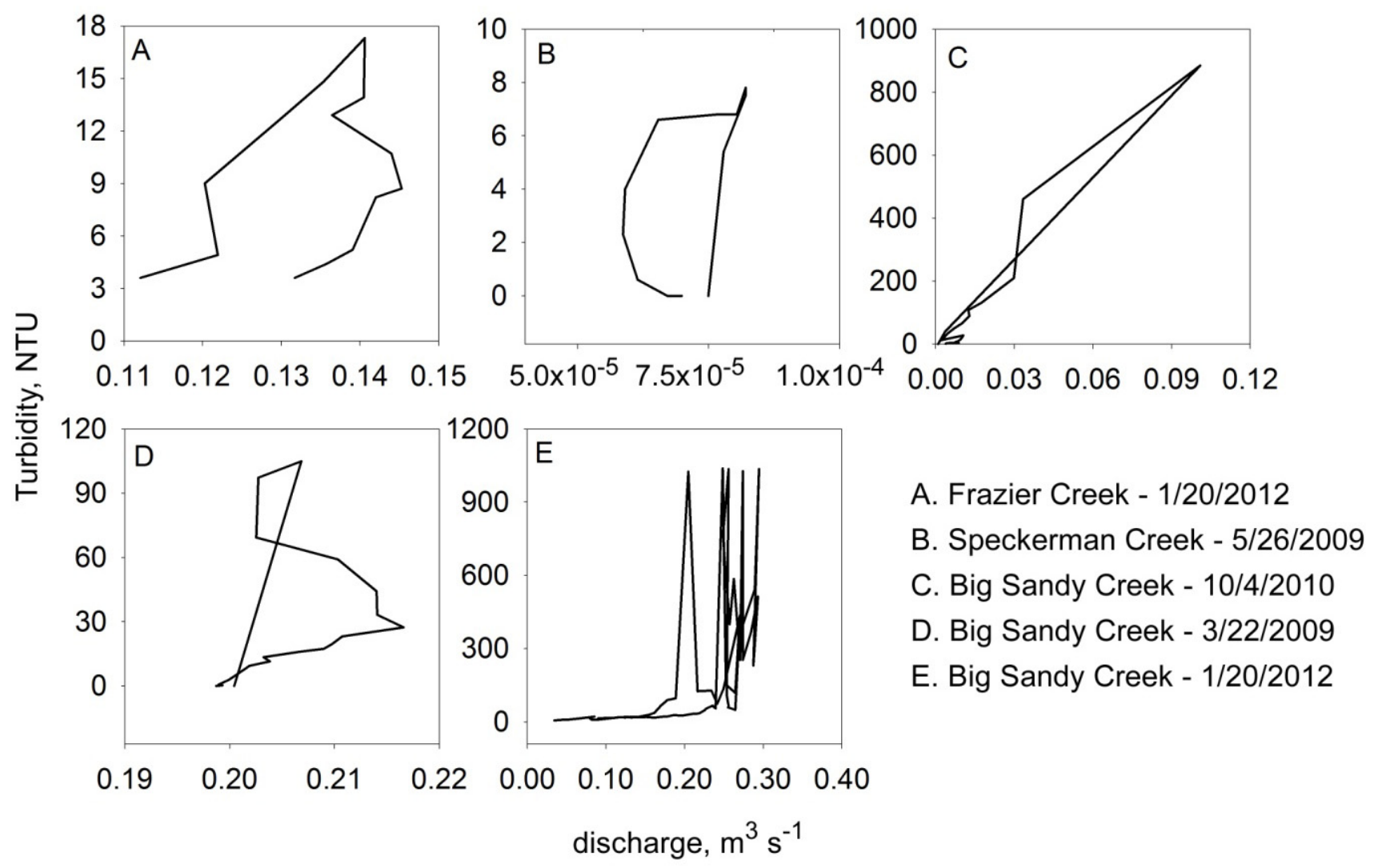


Table 6. Number of hysteresis loop patterns for turbidity events.

\begin{tabular}{ccccc}
\hline Hysteresis shape & Big Sandy & Speckerman & Bear Trap & Frazier \\
\hline Clockwise & 14 & 11 & 5 & 16 \\
Counterclockwise & 3 & 3 & 2 & 0 \\
Linear & 3 & 1 & 0 & 0 \\
Figure Eight & 2 & 4 & 0 & 0 \\
Complex & 3 & 1 & 1 & 1 \\
\hline
\end{tabular}

Clockwise patterns were the dominant event pattern for all seasons except base flow (Table 7). Clockwise events mainly occurred during fall and early/mid winter. The non-clockwise patterned events that occurred during these seasons were generally associated with multi-rise flow events. Clockwise patterns were also dominant for the snow melt period. The baseflow season's more even distribution of hysteresis patterns is thought to be due to turbidity peaks from buildup of organic matter under extremely low flow conditions and not from the movement of material associated with flow-erosion processes. Supporting evidence turbidity is caused by organic buildup is the fact that many of these spikes occurred without any associated rainfall or discharge rise.

Table 7. Number of turbidity event hysteresis loop patterns by season at all study catchments.

\begin{tabular}{ccccc}
\hline Hysteresis shape & Fall & Early/Mid winter & Snow melt & Base flow \\
\hline Clockwise & 18 & 19 & 8 & 1 \\
Counterclockwise & 2 & 2 & 1 & 3 \\
Linear & 3 & 0 & 0 & 1 \\
Figure Eight & 0 & 2 & 2 & 2 \\
Complex & 1 & 3 & 2 & 0 \\
\hline
\end{tabular}

The predominance of a clockwise pattern indicates that localized in-channel sources are likely the most important source of sediment in these catchments. Research in other small headwater catchments in the Sierra Nevada suggests that relatively little hillslope material directly reaches the stream and instead sediment comes from the channel bed and banks [3]. In addition, no clear differences in hysteresis patterns are seen between periods of snow cover and periods of open ground in this study further suggesting that hillslope sediment production may play a minimal role in turbidity patterns. Rodriguez-Blanco et al. [6] similarly found clockwise to be the dominant hysteresis pattern suggesting a localized sediment sources. In contrast to these findings, Fang et al. [14] showed clockwise patterns at the hillslope plot scale and counterclockwise patterns at the basin scale suggesting a dominantly hillslope source at various spatial scales on the Loess Plateau of China. The difference in results between this work and Fang et al. is likely because their site has some of the highest soil erosion rates in the world with an average annual sediment yield of 22,200 tons per $\mathrm{km}^{2}$ and extremely steep slopes of up to 70 degrees [14]. In comparison, sediment yields in the central Sierra Nevada have been estimated to be around 4.1 tons per $\mathrm{km}^{2}$ [3]. For these reasons, hillslopes on the Loess Plateau are likely to dominate over channels as a primary sediment source.

The dominance of clockwise hysteresis loops also has implications on flow pathways in the study catchments. Seeger et al. [18] showed that clockwise loops were the most common for small Central Pyrenees catchments and that this pattern occurred under normal runoff conditions. They showed 
that counterclockwise loops typically only occurred under extremely wet antecedent conditions where overland flow was possible. Additionally, Soler et al. [13] showed that antecedent moisture conditions were important in their dominantly forested catchment where counterclockwise loops were associated with overland flow and implied remote sediment sources within the catchment. The limited number of counterclockwise patterned events along with the characteristically sandy soils suggests that overland flow is extremely rare in typical Sierra Nevada headwater catchments such as the one in this study.

Though clockwise patterns are dominant, that all five hysteresis patterns occur implies there are likely multiple source areas (i.e., in-channel, near channel, or upper hillslopes) and/or multiple source features (i.e., loose material at toe, more consolidated bank material, channel beds with varying degrees of armament) that occasionally come into play. This is to be expected in a mountain catchment with temporal and spatial variations in rainfall, runoff, and discharge. Variations in storm intensities, storm durations, and antecedent conditions result in a range of flow responses and subsequently a variety of hysteresis patterns (Figure 4). The linear, counterclockwise, and complex hysteresis patterns are often associated with multiple storm events that occur in short succession. In this study, extended events with multiple discharge peaks showed a shift in hysteresis loop patterns from a clockwise to a more linear pattern with turbidity and discharge peaking concurrently, and then toward a counterclockwise pattern where turbidity peaks after discharge. The first part of this pattern shift is seen in the multi-rise storm sequence shown in Figure 5, where the hysteresis loop shape starts off clockwise and becomes progressively more linear. The shifts in hysteresis patterns are indicative of shifts in sediment sources. As local sources become more and more depleted, other sources contribute more to turbidity. The shift in pattern associated with multiple storm events (Figure 5) may represent one of two possible scenarios: (1) a shift from loose, easy to erode in-channel material to more cohesive bed/bank material that requires more flow energy to entrain; or (2) a shift from nearby sources (i.e., in-channel stores) to more distant source locations (i.e., upper hillslopes). The more distant sources or more cohesive sources may result in a lag between discharge peaks typical of non-clockwise hysteresis patterns. Lana-Renault et al. [32] and Soler et al. [13] attributed counterclockwise hysteresis patterns in their studies to distant sediment sources or to antecedent conditions that may cause a lag in sediment transport (i.e., subsurface must fill before saturation overland flow can occur). Discharge or precipitation thresholds for the occurrence of counterclockwise hysteresis were not identifiable in this study, however, the number of counterclockwise events was low and with a larger sample size thresholds may be identifiable.

Our conceptual model for the accumulation and depletion of localized sediment stores is that during low-flow periods, sediment accumulates at the toe of banks (Figure 6A). This accumulation period is thought to occur at the seasonal time scale (i.e., summer base flows) as well as event scale (i.e., low flows between discharge peaks). Sediment is entrained and transported downstream during high-flow events, with multiple events in short succession depleting sediment stores (Figure 6B).

Bank surveys were conducted at the end-of-summer low-flow periods each year. In many of these surveys, a pile of accumulated sediment was observed at the toe of banks and can been seen in the bank-profile plots (Figure 7). This accumulated sediment provides supporting evidence to our conceptual model. The stockpiling of sediment in the channel during low-flow periods has been documented in systems of various sizes and hydroclimatic regimes $[4,12,17]$. 
Figure 5. Hysteresis pattern progression can be seen within a multi-rise storm event sequence. (A) clockwise; (B) (less) clockwise; (C) linear.

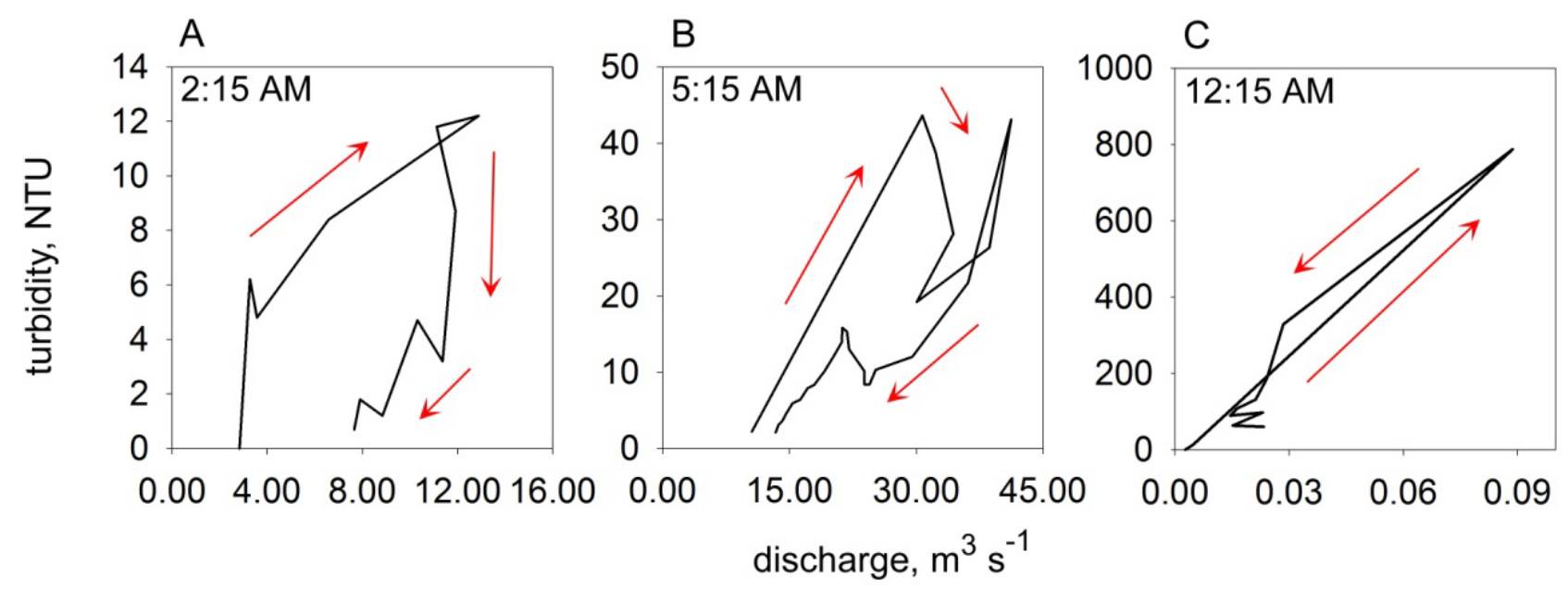

Figure 6. A conceptual model of localized sediment processes consisting of (A) an accumulation phase and (B) a depletion phase.
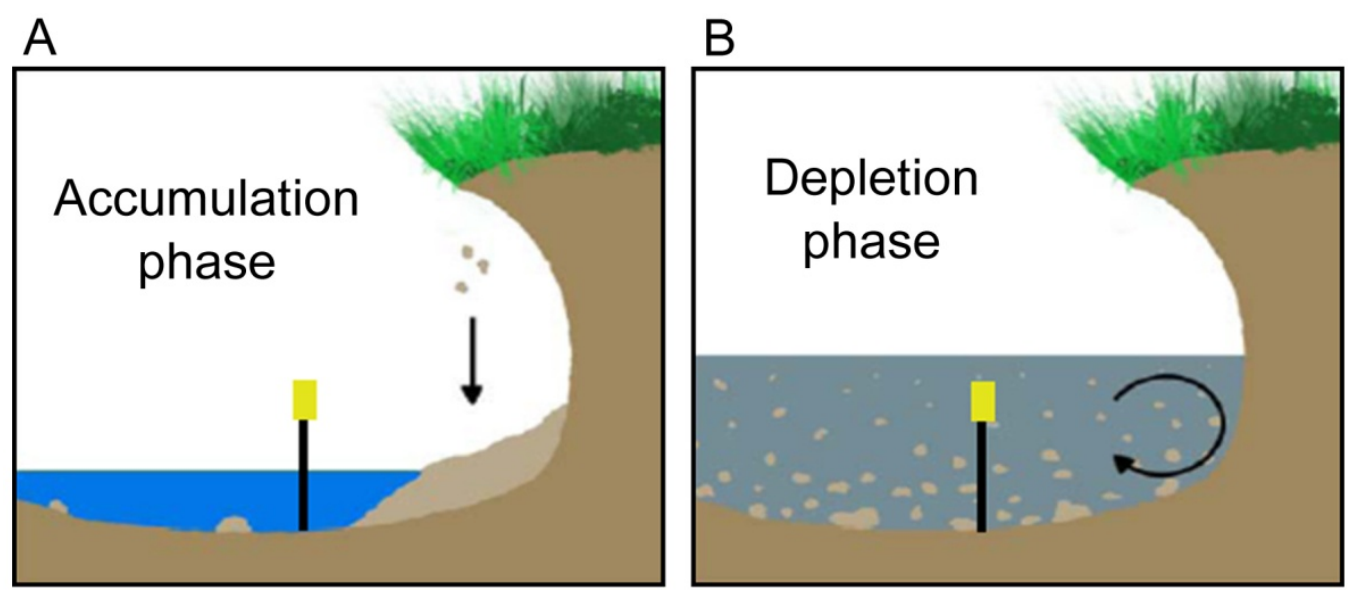

Figure 7. Bank pin surveys from (A) Big Sandy and (B) Speckerman showing sediment accumulation at toe of bank slopes.
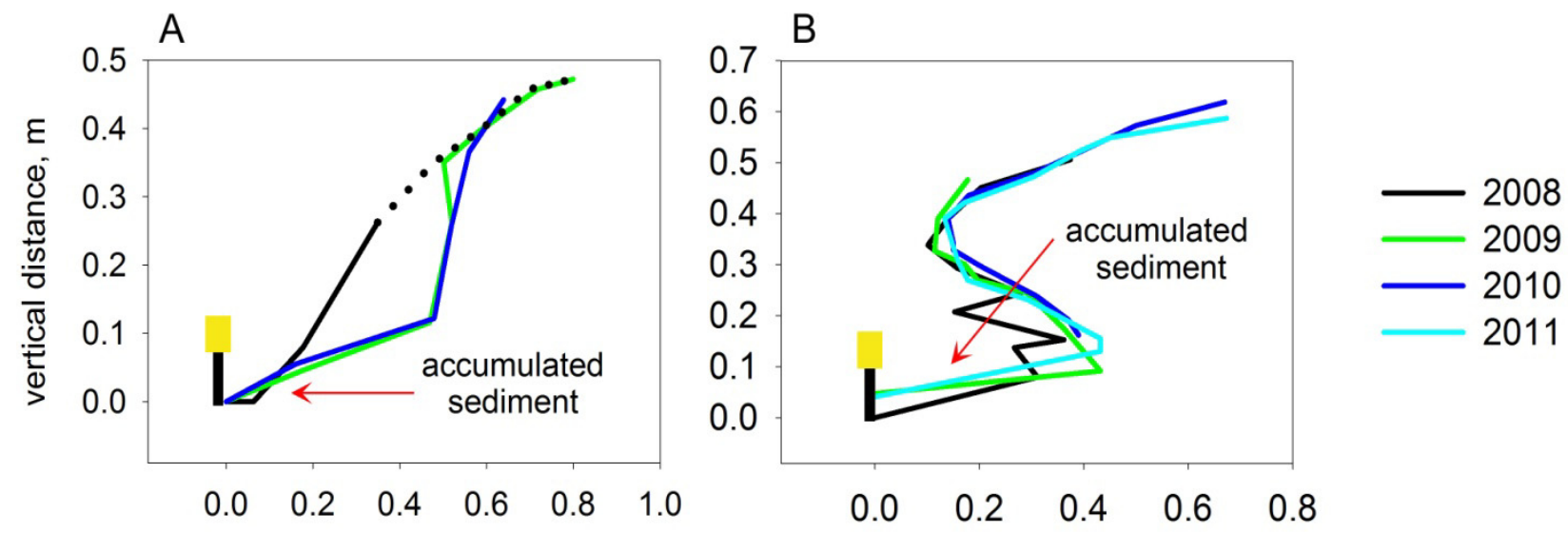

horizontal distance, $\mathrm{m}$ 


\section{Conclusions}

Turbidity and discharge data collected over three years in four small mountain catchments of the Sierra Nevada showed that localized sources of sediment dominate sediment production and that seasonal and event-scale accumulation and depletion cycles govern sediment transport in these streams. The dominantly clockwise hysteresis patterns in all seasons implied that localized-most likely in-channel-sources supplied the sediment for most events and that overland flow is likely rare. In multiple-rise events or events in short succession-where severe depletion of local sources can occur, the shift in hysteresis shapes to non-clockwise patterns indicated that once localized sources were depleted, more distant or more consolidated sources may come into play. Seasonal reductions in peak turbidity values suggest a seasonal scale of sediment depletion also occurs.

Our conceptual model suggests that material accumulates at the toe of banks through physical erosion during periods of low flow when the stream has little energy to move it. The material is transported during periods of higher flow. These cycles may occur on an event scale as indicated by hysteresis patterns where the event peak is the high-flow depletion phase and inter-event periods the low-flow accumulation phase. This accumulation-depletion pattern also expresses itself on a seasonal scale with fall and snow melt seasons representing depletion phases. Base flow and to a lesser extent, early/mid winter seasons represent periods of low flow and sediment accumulation.

Knowing the timing and source areas for sediment that causes turbidity will help managers know when and where to focus erosion control measures and structures. Under normal erosion conditions, the importance of in-channel sources over hillslope sources may indicate in-channel sediment control structures such as weirs or check dams rather than hillslope erosion control measures. Alternatively, hillslope sediment control measures should be limited to cases where significant changes to the system have occurred and hillslope erosion is more likely to overshadow in-channel sources (i.e., fire, roads, logging, or grazing). Additionally, an understanding of the role of snow cover on erosion and turbidity will allow for better planning in the face of a changing snow pack due to climate change. This knowledge will allow management practices to be chosen that will make the most efficient use of erosion mitigation resources.

\section{Acknowledgments}

This is SNAMP publication \#28. The Sierra Nevada Adaptive Management Project (SNAMP) is funded by USDA Forest Service Region 5, USDA Forest Service Pacific Southwest Research Station, US Fish and Wildlife Service, California Department of Water Resources, California Department of Fish and Game, California Department of Forestry and Fire Protection, and the Sierra Nevada Conservancy. The authors would like to thank California Department of Water Resources, US Forest Service, Sierra Nevada Research Institute, and Sierra Nevada Adaptive Management Project personnel for their support and assistance. Additionally we would like to thank the two anonymous reviewers for their thoughtful comments which have helped in strengthening this manuscript. 


\section{Author Contributions}

All three authors chose sampling design and field locations. Sarah Martin set up field sites, conducted field measurements, and analyzed data. Martha Conklin and Roger Bales provided guidance on field measurements and data analysis. Sarah Martin wrote manuscript with guidance and editing assistance from Martha Conklin and Roger Bales.

\section{Conflicts of Interest}

The authors declare no conflict of interest.

\section{References}

1. Mazurkiewicz, A.B.; McGurk, B.J.; Tsang, M. Effect of Snow Covered Area and Delayed Snowmelt on Water Quality and Reservoir Management: 2010 Turbidity Event in Hetch Hetchy Reservoir. In Proceedings of the 79th Annual Western Snow Conference, Stateline, NV, USA, 18-21 April 2011.

2. Leopold, L.B.; Wolman, M.G.; Miller, J.P. Fluvial Processes in Geomorphology, 2nd ed.; Dover Publications: Mineola, NY, USA, 1995; pp. 27-372.

3. Stafford, A.K. Sediment Production and Delivery from Hillslopes and Forest Roads in the Southern Sierra Nevada, California. Master's Thesis, Colorado State University, Fort Collins, CO, USA, 2011.

4. Doomen, A.M.C.; Wijma, E.; Zwolsman, J.J.G.; Middelkoop, H. Predicting Suspended Sediment Concentrations in the Meuse River using a Supply-Based Rating Curve. Hydrol. Process. 2008, 22, 1846-1856.

5. Langlois, J.L.; Johnson, D.W.; Mehuys, G.R. Suspended Sediment Dynamics Associated with Snowmelt Runoff in a Small Mountain Stream of Lake Tahoe (Nevada). Hydrol. Process. 2005, 19, 3569-3580.

6. Rodriguez-Blanco, M.L.; Taboada-Castro, M.M.; Palleiro, L.; Taboada-Castro, M.T. Temporal Changes in Suspended Sediment Transport in an Atlantic Catchment, NW Spain. Geomorphology 2010, 123, 181-188.

7. Gao, P.; Josefson, M. Event-Based Suspended Sediment Dynamics in a Central New York Watershed. Geomorphology 2012, 139, 425-437.

8. Wood, P.A. Controls of Variation in Suspended Sediment Concentration in the River Rother, West Sussex, England. Sedimentology 1977, 24, 437-445.

9. Williams, G.P. Sediment Concentration Versus Water Discharge during Single Hydrologic Events in Rivers. J. Hydrol. 1989, 111, 89-106.

10. Sadeghi, S.H.R.; Mizuyama, T.; Miyata, S.; Gomi, T.; Kosugi, K.; Fukushima, T.; Mizugaki, S.; Onda, Y. Determinant Factors of Sediment Graphs and Rating Loops in a Reforested Watershed. J. Hydrol. 2008, 356, 271-282.

11. Granger, S.J.; Bol, R.; Hawkins, J.M.B.; White, S.M.; Naden, P.S.; Old, G.H.; Marsh, J.K. Using Artificial Fluorescent Particles as Tracers of Livestock Wastes within an Agricultural Catchment. Sci. Total Environ. 2011, 409, 1095-1103. 
12. Wilson, C.G.; Thanos Papanicolaou, A.N.; Denn, K.D. Partitioning Fine Sediment Loads in a Headwater System with Intensive Agriculture. J. Soils Sedim. 2012, 12, 966-981.

13. Soler, M.; Latron, G.; Gallart, F. Relationships Between Suspended Sediment Concentrations and Discharge in two Small Research Basins in a Mountainous Mediterranean Area (Vallcebre, Eastern Pyrenees). Geomorphology 2008, 98, 143-152.

14. Fang, H.; Li, Q.; Cai, Q.; Liao, Y. Spatial Scale Dependence of Sediment Dynamics in a Gullied Rolling Loess Region on the Loess Plateau in China. Environ. Earth Sci. 2011, 64, 693-705.

15. McDonald, D.M.; Lamoureux, S.F. Hydroclimatic and Channel Snowpack Controls over Suspended Sediment and Grain Size Transport in a High Arctic Catchment. Earth Surf. Process. Landf. 2009, 34, 424-436.

16. Iida, T.; Kajihara, A.; Okubo, H.; Okajima, K. Effect of Seasonal Snow Cover on Suspended Sediment Runoff in a Mountainous Catchment. J. Hydrol. 2012, 428, 116-128.

17. Smith, H.G.; Dragovich, D. Interpreting Sediment Delivery Processes using Suspended Sediment-Discharge Hysteresis Patterns from Nested Upland Catchments, South-Eastern Australia. Hydrol. Process. 2009, 23, 2415-2426.

18. Seeger, M.; Errea, M.P.; Begueria, S.; Arnaez, J.; Marti, C.; Garcia-Ruiz, J.M. Catchment Soil Moisture and Rainfall Characteristics as Determinant Factors for discharge/suspended Sediment Hysteretic Loops in a Small Headwater Catchment in the Spanish Pyrenees. J. Hydrol. 2004, 288, 299-311.

19. State of California Sierra Nevada Conservancy. Available online: http://www.sierranevada.ca.gov/ our-region/sierra-water-supply-connection (accessed on 23 June 2014).

20. Snyder, N.P.; Rubin, D.M.; Alpers, C.N.; Childs, J.R.; Curtis, J.A.; Flint, L.E.; Wright, S.A. Estimation Accumulation Rates and Physical Properties of Sediment behind a Dam: Englebright Lake, Yuba River, Northern California. Water Resourc. Res. 2004, 40, doi:10.1029/2004WR003279.

21. Gathard Engineering Consulting. Klamath River Dam and Sediment Investigation; Gathard Engineering Consulting: Washington, DC, USA, 2006. Available online: http://www.fws.gov/ yreka/kri/gecfinalreport.pdf (accessed on 12 November 2013).

22. Dunne, T.; Leopold, L.B. Water in Environmental Planning, 16th ed.; W.H. Freeman and Company: New York, NY, USA, 2002; pp. 713-777.

23. Yellow Springs Instruments 6920 V2 Multiprameter Sonde Specifications. Available online: http://www.ysi.com/media/pdfs/069300-YSI-6-Series-Manual-RevJ.pdf (accessed on 23 June 2014).

24. Martin, S.E. Comparison of In-Stream Sediment Sources and Assessment of a Bank Erosion Model for Headwater Catchments in the Central Sierra Nevada, California. Master's Thesis, University of California, Merced, CA, USA, December 2009.

25. Moore, R.D. Introduction to Salt Dilution Gauging for Streamflow Measurement: Part 1. Streamline Watershed Manag. Bull. 2003, 7, 20-23.

26. Liu, F.; Hunsaker, C.; Bales, R.C. Controls of Streamflow Generation in Small Catchments across the Snow-Rain Transition in the Southern Sierra Nevada, California. Hydrol. Process. 2013, 27 , 1959-1972.

27. Burch, G.J.; Moore, I.D.; Burns, J. Soil Hydrophobic Effects on Infiltration and Catchment Runoff. Hydrol. Process. 1989, 3, 211-222. 
28. Shakesby, R.A.; Coelho, C.D.A.; Ferreira, A.D.; Terry, J.P.; Walsh, R.P.D. Wildfire Impacts on Soil-Erosion and Hydrology in Wet Mediterranean Forest, Portugal. Int. J. Wildl. Fire 1993, 3, 95-110.

29. Duvert, C.; Gratiot, N.; Evrard, O.; Navratil, O.; Nemery, J.; Prat, C.; Esteves, M. Drivers of Erosion and Suspended Sediment Transport in Three Headwater Catchments of the Mexican Central Highlands. Geomorphology 2010, 123, 243-256.

30. Zachar, D. Classification of Soil Erosion. In Soil Erosion; Holý, I.M., Ed.; VEDA Publishing House of the Slovak Academy of Sciences: Bratislava, Slovakia, 1982.

31. Yager, E.M.; Turowski, J.M.; Rickenmann, D.; McArdell, B.W. Sediment Supply, Grain Protrusion, and Bedload Transport in Mountain Streams. Geophys. Res. Lett. 2012, 39, 1-5.

32. Lana-Renault, N.; Regues, D.; Nadal-Romero, E.; Serrano-Muela, M.P.; Garcia-Ruiz, J.M. Streamflow Response and Sediment Yield after Farmland Abandonament: Result from a Small Experimental Catchment in the Central Spanish Pyrenees. Pirineos Revista Ecol. Montana 2010, $165,97-114$.

(C) 2014 by the authors; licensee MDPI, Basel, Switzerland. This article is an open access article distributed under the terms and conditions of the Creative Commons Attribution license (http://creativecommons.org/licenses/by/3.0/). 